\title{
Hermeneutical Injustice, (Self-)Recognition, and Academia
}

\author{
Hilkje C. Hänel \\ Department of Philosophy, Freie Universität Berlin, Habelschwerdter Allee 45, 14195 Berlin, Germany \\ Corresponding author. Email: hilkje.haenel@fu-berlin.de
}

(Received 23 January 2018; revised 12 June 2019; accepted 30 July 2019)

\begin{abstract}
Miranda Fricker's account of hermeneutical injustice and remedies for this injustice are widely debated. This article adds to the existing debate by arguing that theories of recognition can fruitfully contribute to Fricker's account of hermeneutical injustice and can provide a framework for structural remedy. By pairing Fricker's theory of hermeneutical injustice with theories of recognition, I bring forward a modest claim and a more radical claim. The first concerns a shift in our vocabulary; recognition theory can give a name to the seriousness of the long-term effects of hermeneutical injustice. The second claim is more radical: thinking of hermeneutical injustice as preventing what I call "self-recognition" provides a structural remedy to the phenomenon of hermeneutical injustice. Because hermeneutical injustice is first and foremost a structural injustice, I contend that every virtue theory of hermeneutical justice should be complemented by structural remedies in terms of recognition. Finally, what I argue sheds light on the seriousness of cases of exclusion of and discrimination against women in academia and helps to draw our attention to new ways to combat such problems.
\end{abstract}

Key words: Hermeneutical Injustice; Recognition Theory; Self-Recognition; Identity; Academia

Theories of hermeneutical injustice, epistemic injustice, and epistemic violence have gained a wide reception over the last few years (cf. Dotson 2011; Pohlhaus 2012; Hull 2017; Kidd, Medina, and Pohlhaus 2017, to name only a few). This is partly because theories of epistemic injustice have given expression to a phenomenon experienced by many. Recently, there has been further interest in the relation between epistemic injustice and the concept of recognition (cf. McConkey 2004; Pohlhaus 2012, 105-6; Congdon 2017; Bratu and Lepold 2018; Giladi 2018). These inquiries focus on questions such as the normative status of the knower (Congdon 2018) or the possibility of resisting epistemic injustices (Doan 2018; Medina 2018). ${ }^{1}$ The general motivation behind these endeavors can be put like this: philosophically investigating different forms of epistemic injustice can actually help combat these injustices in the social world (cf. Medina 2017, 45). 
With this article, I seek to contribute to this intellectual endeavor. By pairing Fricker's theory of hermeneutical injustice with theories of recognition. I argue that instances of hermeneutical injustice are deeply entangled with relations of misrecognition in at least two senses: they (1) are the result of a prior history of misrecognition (especially, hermeneutical marginalization) and (2) render speakers vulnerable to future acts of misrecognition. ${ }^{2}$ I bring forward a modest claim and a more radical claim. ${ }^{3}$ The first concerns a shift in our vocabulary; according to Fricker, structural hermeneutical injustice can bring about serious harms even in the aftermath of such injustice, for example, the victim of epistemic injustice can be prevented from selfdevelopment. This harmful consequence can be spelled out in terms of recognition. Instances of hermeneutical injustice amount to receiving less or no recognition from others, which can compromise what I call self-recognition. Although this is not a new idea, recognition theory can give a name to the seriousness of the long-term effects of hermeneutical injustice. The second claim is more radical: thinking of hermeneutical injustice as preventing self-recognition includes a shift in our answer to the question of how to tackle hermeneutical injustice. In other words, we should now ask: How can self-recognition be fostered? Following Axel Honneth, we can provide three distinct but interdependent answers: self-recognition can be fostered by love, esteem, and respect. Fricker's own virtue theory of epistemic justice is in line with the first two, but she misses the last one. Her theory focuses on the individual virtues we should develop to thwart hermeneutical injustice. However, hermeneutical injustice is a structural injustice, and thus in need of a structural solution. I argue that respect provides a structural remedy to the problem of misrecognition of hermeneutical injustice and should therefore complement any theory of epistemic justice. My general goal in this article is to show how theories of recognition can add important components to Fricker's theory of hermeneutical injustice and, in particular, help us better understand forms of discrimination and exclusion in academia. Hopefully, this can contribute to finding structural strategies against hermeneutical injustice in general and discriminatory practices in academia in particular.

In the first section, I provide an example of hermeneutical injustice in academia to set the stage for my investigation of hermeneutical injustices. In the second section, I show how misrecognition gives a name to the seriousness of the long-term effects of hermeneutical injustice; in this section, I also provide an account of what I call "selfrecognition." The absence of recognition by others does not occur only in drastic cases such as torture and rape, but can also take place in instances of discrimination or exclusion. In academia, members of minority groups (for example, women) receive less recognition, that is, experience hermeneutical injustice, and are thus compromised in their self-recognition. This can lead to underperformance. Having set the stage by introducing both hermeneutical injustice and recognition theory, I proceed in section III by making explicit the implications of understanding the injustice of hermeneutical injustice as a problem of misrecognition, and I argue in section IV that Honneth's theory of recognition should complement Fricker's virtue account of epistemic justice since it provides a structural remedy. I present conclusions in section V.

\section{Hermeneutical Injustice}

It is by now widely accepted that members of minority groups suffer from implicit mistreatment and outright hostility in academia, especially in philosophy (cf. Haslanger 2008; Yancy 2008; Wylie 2011; Antony 2012; Hutchison and Jenkins 2013; Hänel 
2017) By means of an example, I will show how some of the mistreatment of women in philosophy is a problem of hermeneutical injustice and misrecognition. ${ }^{4}$ This example, even though stylized, is inspired by many women's experiences in academic philosophy (including my own).

Imagine Anna, a philosophy student enrolled in a BA program at a prestigious university. Since she started her studies, Anna has come to realize that women are underrepresented in the upper echelons of academic philosophy. For instance, she has never been able to take a class with a female professor as no such person is employed by her department. Also, she has attended several meetings of the Society of Women in Philosophy where she has seen statistics according to which roughly only twenty percent of all full professorships in philosophy are held by women, even though the number of female students receiving their Master's degrees and even their PhDs is roughly the same as that of male students. At these meetings, Anna has also learned to use a broad concept of discrimination. According to this concept, a person B discriminates against another person $C$ vis-à-vis yet another person D if (1) by $\varphi$-ing, B leaves C worse off than D, (2) B's $\varphi$-ing occurs because $B$ perceives $C$ to be member of some social group $G$, and (3) the situation is such that leaving $C$ worse off is not conclusively justified (Lippert-Rasmussen 2017). Anna's concept of discrimination is broad insofar as discrimination need not occur willfully or even knowingly. But despite her feminist consciousness-raising, Anna has also been taught that academia is structured by the principle of equality of opportunity. Every time her professors give grades to their students, they say that they mark their papers only according to the merit of their content. Of course, not all students will end up with good marks, but that difference is due entirely to their knowledge and studiousness. Furthermore, Anna is part of a culture in which it is still generally believed that women do not have careers similar to men because women simply do not want to get top jobs and instead prioritize other things in life, like childcare.

When Anna fails to get funding for graduate studies but her classmate Bob gets it even though his grades are considerably lower than hers, she is ill equipped to see this as an instance of discrimination despite her knowledge of the profession and her wide conception of discrimination. This is because Anna believes that academia is structured by the principle of equality of opportunity and because there are prevalent alternative narratives that provide her with reasons for why she failed to get funding. In other words, Anna knows about academia's problems with women in general, but, at the same time, she fails to see her own discrimination experience as an instance of it. Despite her having the conceptual resources to make her experience intelligible, she fails to do so because of dominant counter-narratives. Anna fails to conceptualize her experience adequately, because even self-damaging alternative stories have a hold on us. ${ }^{5}$

How do we account for what is happening to Anna? I claim that Anna's failure to make her experience intelligible to herself is a form of hermeneutical injustice. Fricker introduces hermeneutical injustice as a distinctively epistemic wrong, that is, "a wrong done to someone specifically in their capacity as a knower" (Fricker 2007, 1). She then goes on to define hermeneutical injustice 6 as "the injustice of having some significant area of one's social experience obscured from collective understanding owing to a structural identity prejudice in the collective hermeneutical resource" (155). By identity prejudices, Fricker means "judgements, which may have a positive or negative valence, and which display some (typically, epistemically culpable) resistance to counter-evidence" (35) and that affect "people in virtue of an aspect of their social identity" (155). Identity prejudices are structural insofar as they perceive individuals through some group membership and only indirectly relate to the mental set-up of individual 
persons (155). In the case of hermeneutical injustice, the structure affected by identity prejudices is a society's collective hermeneutical resource.

Fricker illustrates how identity prejudices can lead to hermeneutical injustice by discussing two examples. First is the case of Wendy Sanford, who blamed herself (and who was also blamed by her husband) for being a bad mother. However, a friend brought her along to a feminist consciousness-raising meeting, where she learned the concept of postpartum depression. This helped her realize that what she had been experiencing was not a "personal deficiency," but "a combination of physiological things and a real societal thing, isolation" (149). The second case is that of Carmita Wood, who felt "ashamed and embarrassed" (150) by the sexual behavior of one of her superiors. ${ }^{7}$ After she quit her job in order to avoid his aggressive advances, she was unfairly denied unemployment benefits. Fricker contends that Wood could not gain "a proper understanding" (151) of her situation because she did not possess the concept of sexual harassment-a term coined by feminists to denounce such outrageous behavior as that of Wood's superior. In both cases, the women affected by hermeneutical injustice were prevented from coming to a correct assessment of their experience. Yet there is an obvious difference between Wendy Sanford or Carmita Wood and the woman in our example, Anna. Whereas Sanford and Wood were prevented from an adequate assessment of their situations because of a gap in the collective hermeneutical resource-the terms postpartum depression and sexual harassment were not available to them when they needed them to beAnna does not suffer from a lack of suitable concepts. In fact, Anna has all the relevant concepts at her disposal, but still fails to assess the experience adequately.

To make sense of this phenomenon, I now turn to some competing accounts of hermeneutical injustice. Charlie Crerar claims that there can be cases of hermeneutical injustice where an agent has all the relevant concepts at hand, and where these concepts are adequate (Crerar 2016), ${ }^{8}$ but the agent still fails to use them due to interfering societal taboos. To make his case, Crerar claims that the specific taboo concerning menstruation prevents women from developing an accurate understanding of their experiences. Hence, he concludes that we need to expand Fricker's account to accommodate other examples besides the ones that Fricker uses, in which the injustice amounts to lacking a relevant concept. However, as Ishani Maitra, and Christine Bratu and I argue (Maitra 2018; Bratu and Hänel 2019), Fricker's original definition of hermeneutical injustice is broad enough to accommodate a wide range of cases already; the call for expansion is therefore unnecessary. Maitra notes that according to the definition given above, hermeneutical injustices do not necessarily need to involve hermeneutical gaps and that the notion can be used whenever there is a hermeneutical interference with our understanding (Maitra 2018, 3). Christine Bratu and myself argue that Fricker brings forward two things: a broad definition of hermeneutical injustices and narrower examples of the same phenomenon (Bratu and Hänel 2019, unpublished manuscript). Hence, one could easily be misguided in thinking of hermeneutical injustice as a narrow notion, when in fact the given definition is sufficiently broad to encompass a whole range of cases. Accordingly, Anna's example can be understood as a case of hermeneutical injustice. Although Anna does not suffer from a gap in the collective hermeneutical resource, she is prevented from understanding her experience adequately due to the hermeneutical interference of misguided but dominant background narratives of academia. Such narratives are structured by the principle of equality of opportunity and the myth that women do not want to stay in academia.

If Anna's case is an example of hermeneutical injustice, then we can ask, what does the hermeneutical injustice do to her? In other words, what is the particular harm that 
is done to victims of hermeneutical injustice? According to Fricker, hermeneutical injustice leads to (at least) two distinct harms, a primary harm and a secondary harm. The primary harm of hermeneutical injustice "consists in a situated hermeneutical inequality" (Fricker 2007, 162, emphasis in original). The epistemic agent is excluded from contributing to the collective hermeneutical resource on the grounds of a structural identity prejudice; the agent is excluded from participating in the production of knowledge. Furthermore, as Katharine Jenkins convincingly argues, such exclusion also robs agents of their ability to contest the unfair treatment that they received (Jenkins 2016, 11). The secondary harm concerns the practical consequences that result from the hermeneutical exclusion. Experiencing hermeneutical injustice is harmful because "it tends to knock your faith in your own ability to make sense of the world, or at least the relevant region of the world" (Fricker 2007, 163). Hence, according to Fricker, failing to understand one's situation leads to cognitive dissonance, and this in turn entails a "loss of epistemic confidence" (163) in oneself. Such a loss of epistemic confidence is unsettling and harmful in itself, but it also "brings secondary epistemic disadvantages" (163) as it might prevent the people affected from gaining new knowledge or important epistemic virtues (cf. 163), such as intellectual courage, for instance. Thus, Anna is at least doubly harmed: she is harmed by the hermeneutical exclusion and by the consequences that such an exclusion has in regard to her epistemic confidence. However, Fricker argues that the primary harm of hermeneutical exclusion can lead to a further disadvantage. Hermeneutical injustice can result in the social constitution of agents into something they are not, or into something that is not in their interest to be. In other words, hermeneutical injustice can prevent agents "from becoming who they are" (168). This is especially the case in cumulative and severe acts of hermeneutical injustice, which can harm an agent even in the aftermath of the actual situation of injustice. Accordingly, hermeneutical injustice can "sometimes [be] so damaging that it cramps the very development of self" (163).

Next, I turn to theories of recognition to show that they can give expression to the seriousness of this additional harm of hermeneutical injustice. This is a modest claim. I propose a redescription of the harm of hermeneutical injustice that highlights the longterm suffering that cases of hermeneutical injustice can yield as well as the psychological effects on its victims. I argue that when hermeneutical injustice prevents agents from becoming who they are, we can adequately express this harm in terms of misrecognition. I attempt to do so by highlighting the relation between acts of recognition and what I call self-recognition, and the relation between self-recognition and hermeneutical injustice. Roughly, the harmful experience of hermeneutical injustice not only leads to loss of epistemic confidence, but also compromises who we think we are. By framing hermeneutical injustices as problems of misrecognition, we can see the relation between these injustices and self-recognition, that is, our self-respect, self-esteem, and selfconfidence. To do so, I will first look at some theories of recognition and misrecognition. Second, I will introduce the term self-recognition, and third, I will bring forward an argument according to which hermeneutical injustice amounts to a problem of misrecognition and thus compromises self-recognition.

\section{The Wrong of Hermeneutical Injustice: Compromising Self-Recognition}

Contemporary recognition theory has its roots in writings as far back as Rousseau, but it is most commonly associated with German idealism, especially the theories of Fichte and Hegel. ${ }^{9}$ Both Fichte and Hegel were concerned with how structures of 
intersubjectivity and intersubjective recognition are constituted. Their ideas were taken up by Marx in his early analysis of the social relations of wage-labor, including both their identity-constituting character and capitalist deformations, such as became clear with the concept of alienation (cf. Zurn 2010,2). Theories of recognition are always linked to theories of identity, where identity means "a person's understanding of who they are, of their fundamental defining characteristics as a human being" (Taylor 1994, 25). The underlying idea is that who we are is shaped by recognition, misrecognition, or the absence of recognition by others. This identity-recognition relation implies that

a person or group of people can suffer real damage, real distortion, if the people or society around them mirror back to them a confining or demeaning or contemptible picture of themselves. Nonrecognition or misrecognition can inflict harm, can be a form of oppression, imprisoning someone in a false, distorted, and reduced mode of being. (25)

Take the example of women in patriarchy. Feminists have long argued that women who live in patriarchal or sexist social systems come to have a distorted image of themselves. They see themselves as inferior or as objects whose purpose it is to please and submit. This implies that even when women's external social conditions improve, they cannot so easily free themselves from their distorted self-understanding, their self-hatred and low self-esteem. ${ }^{10}$ Thus, Charles Taylor is correct in stressing that misrecognition is more than "just a lack of due respect," rather it is the absence of a "vital human need" (26). What is important here is the idea that as social agents, we can flourish only if we have meaningful relationships of (mutual) recognition. In other words, we fail to identify with our experiences and actions unless we do so in relation to others and within a community (cf. Taylor 1994; Neuhouser 2000; Pippin 2008; Honneth 2011). Thus, recognition not only helps us to value our own projects but makes it possible for us to have such projects in the first place. This implies that misrecognition or the absence of recognition can impede our investments in our own projects and in who we are. $^{11}$

Many recognition theorists distinguish among three different forms of recognition: (1) equal recognition for all persons; (2) differential recognition of the uniqueness of specific features; and (3) recognition of individuality in contexts of care (cf. Taylor 1994; Honneth 1995). The first and second form are also often referred to in terms of "equal respect" and "esteem due to one's achievements," the third one as love and/or friendship. These three forms of recognition are already present in Hegel's writings and are still the main focus of the contemporary debate. According to Honneth, they comprise the distinct stages that individuals go through when they gain selfconfidence, self-respect, and self-esteem (Honneth 1995). ${ }^{12}$ In other words, these three forms of recognition-respect, esteem, and love-are intersubjective conditions that are needed for agents to develop self-respect, self-esteem, and self-confidence; it is because of these forms of recognition that we can constitute our own identity. For Honneth, these three forms of recognition-gained from our legal relations, our communities, and our primary relationships-build different components of our personality. Analogous to the three forms of recognition-respect, esteem, and love-Honneth distinguishes among three forms of misrecognition: (1) denial of rights and exclusion; (2) denigration and insult; and (3) physical abuse, torture, and rape. The first shatters the self-respect of victims, the second shatters their self-esteem, and the third robs them 
of their basic self-confidence. By doing so, the three forms of misrecognition threaten different parts of people's identity: their social integrity, their honor and dignity, and, lastly, their physical integrity (Honneth 1995, 129).

I agree with Honneth that misrecognition can shatter different parts of a person's identity. However, I want to remark that a person's identity cannot be neatly split into three different parts-social integrity, honor and dignity, and physical integrity - where each part is threatened by a different form of misrecognition. For example, it is not the case that a rape victim's mere physical integrity is shattered by an act of rape. Instead, rape victims report that the attack against them destroys their bodily integrity as well as their social integrity and their honor and dignity. Susan Brison describes in detail how the violence of rape can shatter victims' trust in themselves, in their bodies, and in the world around them (Brison 2002). One of the horrors of rape is precisely that it destroys not merely victims' physical integrity but also their social integrity and dignity. This is why many moral philosophers have argued that rape should be understood as an act of dehumanization, "soul murder," or moral injury (cf. Gardner and Shute 2000; Archard 2007; Miller 2009; Bernstein 2015; Mikkola 2016). Furthermore, we should not so readily assume that only acts of abuse and rape can destroy a person's basic self-confidence, whereas denial of rights and denigration instead destroy someone's self-respect and self-esteem. Rather, acts of discrimination or denigration and insult-especially if these are experienced over a longer period-can lead to the destruction of a person's self-confidence as well. For example, Frantz Fanon famously writes about the shame and self-contempt he felt from being singled out as a black person and the ways in which his black identity is constructed by others and adopted by him (Fanon 1952/2008). Being denied the same treatment as everyone else or being addressed differently from others can indeed lead to the loss of self-confidence-even if this is a slow and unconscious process and thus quite different from a violent attack. Let us instead claim that a person's identity is composed of many overlapping parts-for example, social integrity, honor and dignity, and physical integrity-where all of them can be threatened by acts that deny someone's due respect, esteem, and care. This is important for seeing the relation between hermeneutical injustice and self-recognition, since acts of hermeneutical injustice are precisely not acts of abuse but acts of exclusion and denigration.

We can now say that recognition in the form of respect, esteem, and love provide the necessary elements from which we can develop self-respect, self-esteem, and selfconfidence so as to shape our identities. As I have argued above, it is not only one form of misrecognition that can threaten just one part of our identity, but rather, any misrecognition can threaten our entire identity as such. I will thus use the term selfrecognition when referring to the cluster of self-respect, self-esteem, and selfconfidence. ${ }^{13}$ Hence, misrecognition or the absence of recognition-be it in the form of denial of rights and exclusion, denigration and insult, or abuse and rape-can threaten our self-recognition. And self-recognition is an essential component of our identity. It is necessary for us to have projects and to value these projects. In other words, recognition has a causal relation to self-recognition and therefore for our capabilities to define ourselves and to make and value our own projects (cf. Honneth 1995). Here I make a psychological claim. In some instances, misrecognition or the absence of recognition causally brings about compromise of our self-recognition.

What then is the relation between self-recognition and hermeneutical injustice? At first glance, it might seem that misrecognition and hermeneutical injustice are two very distinct phenomena that have nothing in common. However, I want to argue 
that hermeneutical injustice can be understood as a problem of misrecognition. ${ }^{14}$ Roughly, my argument goes as follows. Self-recognition is conditioned by recognition from others (either through love and esteem or through [partly institutional] respect), and self-recognition can be compromised by misrecognition or the absence of recognition by others. Hermeneutical injustice-the wrong done to someone in their capacity as a knower-is the result of a prior history of acts of misrecognition. Being hermeneutically marginalized (the precondition for suffering from hermeneutical injustice) is due to a lack of respect and esteem that we owe persons as knowers. Furthermore, hermeneutical injustice can compromise recognition by others and thus curtail self-recognition. Hermeneutical injustice occurs when one is unable to understand and articulate a (harmful) experience due to a structural identity prejudice that excludes certain groups from properly participating in our knowledge practices. In some cases, when we fail to articulate our experiences to others, we also fail to gain their recognition. We fail to gain recognition in these cases in two ways: (1) We fail to articulate our experience because of a conceptual lack or social hindrance, and (2) because the listener does not commit to understanding our experience. ${ }^{15}$ Consider (1): we fail to adequately understand and articulate our experience due to a structural identity prejudice that prevents the collective hermeneutical resource from containing or developing the conceptual means required to make sense of our social lives. This is because, structurally, we are not granted the same recognition as others. Consider Fricker's paradigmatic examples of hermeneutical injustice. Wendy Sanford and Carmita Wood were unable to fully understand and articulate their experience of postpartum depression and sexual harassment because both concepts were missing from the collective hermeneutical resource. The collective hermeneutical resource was lacking these concepts because some social groups, that is, (black) women, had less power to contribute to it. In other words, the social group of women was granted less epistemic authority than other social groups such that women were unable to contribute to the resource in similar ways. This can be redescribed as a recognition problem. Members of some social groups receive less recognition than others. They are excluded from contributing epistemically in significant ways.

Next consider (2): when we try to articulate a (harmful) experience, we are vulnerable, we expect acknowledgment and sympathy on the part of the listener. We would not try to articulate our experience knowing that the response would be silence, disbelief, or contempt. In fact, this is precisely why so many victims of sexual violence refrain from telling others about their experiences-they suspect (and often rightly so) that the articulation of what happened to them would not be met with sympathy. When such a personal encounter ends with silence, disbelief, or contempt, then the listener feels entitled to doubt either my experience as such or its harmful consequences. In other words, the listener refuses to acknowledge my special standing as a person who can be harmed and wronged. This, again, is a failure of recognition. Furthermore, even in cases in which I lack the conceptual resources to express my experience clearly, I still expect the listener to acknowledge my feelings and to try to understand what happened to me when I attempt to articulate my experience. If listeners refuse to engage in this effort, they already fail to grant me the same recognition that they would give others. Again, this is often because the person who tries to articulate an experience is part of a social group that receives less epistemic authority. Thus, listeners either fail to realize that they make less effort to understand the experience of the other person or they discard it as unproblematic due to the social group membership of the other. I will 
return to this point shortly. In both cases, (1) and (2), it is because of our membership in a specific social group that we lack recognition in a personal encounter (esteem or love) and in the social structure at large (respect).

Framing hermeneutical injustice as a problem of recognition enables us to claim that hermeneutical injustice not only compromises recognition-those who suffer from hermeneutical injustice have suffered from misrecognition or the absence of recognition and are vulnerable to future acts of misrecognition or the absence of recognitionbut it also compromises self-recognition. In other words, instances of hermeneutical injustice are harmful because they can leave us without self-respect, self-esteem, and self-confidence; they destroy our capability to form an identity. And, because hermeneutical injustice is due to a structural identity prejudice, members of marginalized social groups in particular suffer from past and future misrecognition and are compromised in their personal identity. This is in line with arguments that misrecognition is a form of oppression: it leaves people with a false view of themselves (cf. Taylor 1994; Ferrarese 2009). But this is doubly so insofar as misrecognition targets primarily subjects who are already victims of oppression due to their social group membership. To sum up, the harm of hermeneutical injustice can be redescribed as misrecognition (or the absence of recognition), and as misrecognition it prevents agents from developing self-recognition, or what Fricker called the construction of selfhood. This draws our attention to the seriousness of hermeneutical injustice. Furthermore, being prevented from developing self-recognition highlights the long-term suffering that hermeneutical injustice can yield as well as the psychological effects on the victims of hermeneutical injustice. And, finally, it directs our attention to the subtleties of interpersonal communication; even in cases in which the relevant concept is missing, the listener should have made an effort to understand the pain of the speaker, but fails to do so. In the next section, I focus on these long-term and psychological effects and, in section IV, I propose that taking seriously the claim that hermeneutical injustice compromises selfrecognition suggests that there is a general moral requirement to give recognition: either by granting esteem or (institutional) respect. ${ }^{16}$ I then take the proposal for such a moral requirement to flesh out the structural dimension of recognition in the form of respect and bring forward a more radical claim, namely that recognition theory should complement any virtue theory of epistemic justice for its potential as a structural remedy.

\section{What We Gain: The Framework of Recognition}

We can now say that Anna receives misrecognition in two ways. First, Anna and those with similar experiences of discrimination could not and cannot contribute to the epistemic landscape in similar ways to those who do not experience discrimination; this means that stories of discrimination are not as widely shared as counter-narratives such as the view that academia is a meritocracy. And, second, Anna does not receive sympathy for her story because it is assumed that she did not work hard enough or that she willingly chose a different path. That is, Anna is not granted the same recognition and her harm is not acknowledged. This has consequences for who she thinks she is. In fact, if this is true, then we have to conclude that incidents of hermeneutical injustice in academia-such as the one Anna experiences-not only directly harm individuals because they hinder them from adequately understanding their own experience, but also indirectly harm them because they compromise their self-recognition. ${ }^{17}$ The way academia is set up means that Anna is granted less recognition than others, which has implications for how she defines herself. This is an important insight for 
academia. The cumulative effects of misrecognition or the absence of recognition in academia are self-reinforcing, that is, they influence future behavior in academia and elsewhere. ${ }^{18}$ Each encounter of discrimination or exclusion leaves Anna with less selfrecognition, which in turn means that Anna is less forceful about her ideas and her epistemic contributions (that is, her standing as a knower), has less trust in her own work, is less confident in academic encounters, and so on. Unfortunately, all of the above can (together and separately) lead to receiving less recognition by others (cf. Lane, Lane, and Kyprianou 2004). In other words, the lack of self-recognition produces an asymmetrical relationship for future communications and a downward spiral for Anna's academic success. Hence, academic exclusion is not only harmful to academic success but has direct consequences for a person's identity. Obviously, not all cases of exclusion or discrimination in academia lead to diminished self-recognition. First, this is only the case when a person is unfairly disadvantaged by the collective hermeneutical resource, when the person is part of an already marginalized group. Second, self-recognition is often compromised because of the cumulative aspect of hermeneutical injustices. People who experience only fleeting encounters with such injustice are not often compromised in their self-recognition. Similarly, people who were able to build a strong sense of selfrecognition beforehand, for example, through love during their childhood and esteem later in life, are not as easily compromised in their self-recognition as those who did not have such a fortunate childhood (cf. Keshky and Samak 2017). The degree to which the self-reinforcing effects of misrecognition are actualized and have consequences for a person's identity depends on that person's existing self-recognition (cf. Aguilar and Nightingale 1994). As a woman in academia, one is very likely to suffer from cumulative misrecognition and, due to being socialized as a girl and woman, not to have a strong sense of self-recognition beforehand. Hence, it is likely that women in academia suffer from diminished self-recognition.

Furthermore, the degree to which the self-reinforcing effects of misrecognition are actualized and have consequences for a person's identity also depends on who fails to give recognition (cf. Valkenburg, Peter, and Schouten 2006). As remarked before, as social agents, we develop our own identities particularly in dialogue with others who are close to us. ${ }^{19}$ Taylor argues that we "do not acquire the languages needed for self-definition on [our] own. Rather, we are introduced to them through interaction with others who matter to us-what George Herbert Mead called 'significant others"' (Taylor 1994, 32). It is through conversation with those close to us that we define ourselves-either in dialogue with or in struggle against them. In other words, the recognition of those close to us is of particular importance to our self-recognition, as is the misrecognition or lack of recognition from them. It shakes us in quite different ways if our father does not give us our due recognition than if recognition is not forthcoming from the bus driver whose bus we take to school or the fleeting encounter we had this morning when walking the dog. Our father's misrecognition has a lasting and deep effect on us and can seriously hinder our self-recognition. Unless we already have very low self-esteem, the bus driver's misrecognition will not have the same effect on us.

The misrecognition or lack of recognition from "significant others" can be especially devastating for our self-recognition. ${ }^{20}$ That is, those close to us have a major impact on our identity and our self-recognition. However, we can expand this claim such that it enables us to include not only those close to us in a straightforward sense, such as our family, our partners, our friends, and so on, but also those close to us intellectually. As philosophers, we build our identity at least partly from conversation and struggle with other philosophers. And though we do not need their agreement to recognize 
ourselves as their philosophical peers, we do need their recognition in terms of esteem. In other words, the misrecognition or lack of recognition from those in our philosophical communities can have similarly damaging effects on our self-recognition as the misrecognition from our significant others. And since "being a philosopher" is not a part of our identity that we could decide to abandon easily, but is instead a defining feature of who we are, being misrecognized by our philosophical peers is even more damaging. To sum up, academia, and especially philosophy, grants less recognition to women (and other minority groups) and thus compromises women's selfrecognition. That is, women in academia are likely to have diminished self-respect, less self-esteem, and less self-confidence.

This can lead to underperformance such that women in academia judge themselves to be worse in what they do than they actually are, and therefore produce worse results. The problem of underperformance has gained wide attention in the research on stereotype threat. Stereotype threat

affects the way that members of [a stigmatized] group actually perform. Victims of stereotype threat underperform on the relevant tasks because they are unconsciously preoccupied by fears of conforming to stereotypes about their groupso preoccupied that they show elevated heart rates and blood pressure.. . . Victims of stereotype threat are often, though not always, unaware of what is happening. (Saul 2013, 41-42; see also Steele 2010, 119-20)

Stereotype threat works whenever a person is reminded of the fact that she is a member of a social group for which a stereotype exists that is counterproductive for the task at hand. For example, when they are in so-called threat-provoking situations, women perform worse than men in math tests, blacks perform worse than whites in standardized tests, and so on. Threat-provoking situations are situations in which a person "is from a group that is negatively stigmatised in a certain context, [the person] is in that context, and [the person]'s group membership is made salient" (Saul 2013, 42), for example, when women are asked to state their gender before taking a math test. However, when the threat is absent, there is hardly any difference between the performance of the stereotyped group and that of the other. Jennifer Saul shows how bad stereotype threat is for women in philosophy as it brings women to perform worse than they otherwise could (Saul 2013).

The phenomenon of underperformance due to stereotype threat is slightly different from underperformance in regard to compromised self-recognition. Women in academia whose self-recognition is compromised underperform because they define themselves as less intelligent, productive, and so on. That is, they internalize the misrecognition from others. Although the psychological process might be similar to instances of stereotype threat, underperformance due to compromised self-recognition is far more persistent than underperformance due to stereotype threat. Above, I discussed Taylor's example of women who come to adopt the distorted image of themselves displayed by patriarchal norms. Even when external circumstances are better, these women still suffer from their distorted definition and cannot simply switch their identity. Misrecognition or the absence of recognition motivates members of marginalized social groups to adopt distorted identities of themselves. It is because of their distorted identity that women in academia underperform in tasks that they are otherwise well suited to perform. 


\section{Hermeneutical Injustice and Structural Remedies}

So far, I have brought forward a modest claim: understanding the harm of hermeneutical injustices as a problem of misrecognition gives a name to the seriousness of the harm and the long-term psychological effects that it can bring about. Let me now turn to the more radical claim about pairing the theory of hermeneutical injustice with recognition theory. Consider Anna again, who suffers from hermeneutical injustice in academia, along with its primary and secondary harms. The primary harm of being excluded from contributing to knowledge practices manifests itself in the very construction of Anna's selfhood. Being denied academic recognition, Anna becomes uncertain about her intellectual capacities, her epistemic value, and, ultimately, about being a philosopher. Fricker suggests that a remedy for hermeneutical injustice is to develop the virtue of hermeneutical justice. She writes,

[t]he form the virtue of hermeneutical justice must take, then, is an alertness or sensitivity to the possibility that the difficulty one's interlocutor is having as she tries to render something communicatively intelligible is due not to its being nonsense or her being a fool, but rather to some sort of gap in collective hermeneutical resources. (Fricker 2007, 169)

But Anna's diminishing of self-recognition started long before she tried to articulate her experience and would develop further even without Anna trying to talk about her experiences. In Anna's case, an alert listener would not do the trick. Furthermore, as others have argued, hermeneutical injustice is a structural injustice and thus in need of structural remedies (cf. Anderson 2012; Doan 2018). Elizabeth Anderson, for example, points to the implicit nature of many biases that bring about epistemic injustices, as in Anna's case. Anna's downward spiral of misrecognition was triggered by implicit biases against women's capabilities in philosophy. I want to suggest that the real insight from recognition theory comes from a new answer to the question of how to tackle hermeneutical injustice. With the help of recognition theory, we can ask: How can selfrecognition be fostered? As we have seen in the last section, a solid sense of selfrecognition can work as a defense against misrecognition and as a resource to protest acts of misrecognition (and, thus, hermeneutical injustices).

According to Honneth, recognition comes in at least three ways: as respect, esteem, and love. Hence, if people receive enough respect, esteem, and love, they are wellequipped to develop self-recognition-hopefully enough to withstand hermeneutical injustice. Whereas esteem and love are individualistic notions, respect is not. Respect confers moral worth in a universal sense; we deserve respect qua being persons. Esteem, on the other hand, confers moral worth that is given on grounds of an individual's distinctive character or accomplishments. Finally, love confers care and attentiveness, and shows the beloved person that she is worthy of support and nurture (Honneth 1995, 92-130). Recognition theories that focus on identity have not been without critics. Nancy Fraser, for example, argues that so-called identity-recognition tends to overlook structural injustices. She asks, "Is recognition really a matter of justice, or is it a matter of self-realization?" (Fraser 2003, 27), where the former is her own view and the latter the view she attributes to Honneth. For Honneth, as well as for Taylor, recognition is a "vital human need," and if we do not have experiences of recognition by others, then we fail to define ourselves. Thus, according to Honneth, misrecognition is a social injustice. In fact, it is the primary social injustice because it violates "the social confirmation or 
affirmation of our identity claims" (Kompridis 2007, 278). According to Fraser, on the other hand, recognition does not have a primary causal relation to self-realization or identity-formation, but is instrumental for us to acquire full status as partners in any kind of social interaction. Recognition is thus about social status and not about identity. ${ }^{21}$ Instead of making psychological claims about identity, we should focus on social patterns that deem some social groups "as inferior, excluded, wholly other, or simply invisible" (Fraser 2003, 29). Recognition and misrecognition are not merely interpersonal failures, rather they are grounded in "institutionalized patterns of cultural value, which regulate social interaction in ways that impede parity of participation" (Fraser 2007, 310). In other words, misrecognition is a structural injustice. $^{22}$

We need not reject the interpersonal dimension to acknowledge that recognition and misrecognition are also structural phenomena. In fact, we can endorse the psychological claim that recognition is causally linked to how we define ourselves as well as the structural claim. It is because as social agents we have a certain social status that we are capable of developing who we are. Furthermore, although we often have experiences of recognition or misrecognition in interpersonal encounters, these are not arbitrary interpersonal achievements or failures, but instead stem from a social system in which members of some social groups enjoy more power and more recognition than members of other social groups. For example, women in academia often enjoy less recognition than, for example, men. This can also be expressed with Honneth's idea of three distinct forms of recognition. Whereas esteem acknowledges the specific individual achievement of a person, respect is a universal acknowledgment. Women in academia are often misrecognized in both ways: they lack esteem for the specific contributions they make, but they also lack respect for being knowers in the first place. It is precisely the idea that we can be harmed as knowers that started the discussion of epistemic injustice and violence. And, though instances of misrecognition often happen in contexts of interpersonal encounters, it is not due to someone's personal sympathy for the other person whether they grant recognition or not but due to the (often unjust) social schemas of who "deserves" recognition and who does not. Thus, I want to endorse the psychological claim that recognition is linked to our identity and can thus compromise our self-recognition, while at the same time acknowledging that recognition as much as any other form of power is a structural phenomenon. It is the insight that misrecognition is a structural phenomenon that makes it especially useful in regard to hermeneutical injustice. $^{23}$

The structural component that recognition theory can lend to the notion of hermeneutical injustice turns on the idea of the normative status of being a "knower." In short, having standing as a knower means being recognized as such. Let me explain. We might not have an equal right for esteem or love, but we do for respect. That is, as persons, we deserve respect. Hence, individuals as well as institutions have a general moral and legal requirement to give recognition in the form of respect to others. In cases in which we fail to give respect, we not only disrespect another person, but we deny them their personhood; we dehumanize them. In a recent and insightful article, Matthew Congdon shows that being a knower is an irreducibly ethical concept. He argues that Fricker's negative claim about our vulnerability to wrongdoing, which stems from our hermeneutical powers and epistemic access to the world, also implies a positive claim:

[T] hat being a knower is essentially to bear a normative status that is simultaneously epistemic and ethical: it is epistemic insofar as the label "knower" indicates 
the roles one may legitimately assume within practices of justification and warrant, and ethical, in the sense that being a "knower" implicates one within interpersonal relations of answerability that invoke notions of justice and injustice, flourishing and degradation, virtue and vice, rightful treatment and moral injury. (Congdon 2018, 2)

Having epistemic agency, being a knower, means having a certain normative standing. From here, Congdon argues that "simply in describing someone as a bearer of epistemic agency" means ascribing "to that person an ethical normative standing" (2). Hence, qua our being as persons and knowers, we deserve recognition in the forms of respect and epistemic respect, where epistemic respect conveys "the acknowledgement of the minimal set of capacities we grant to any knower" (Congdon 2017, 249). These are the minimal forms of recognition that we deserve irrespective of our individual capacities or our specific relations to others; as interrelated humans we deserve respect as well as epistemic respect. If we fail to give someone these basic forms of respect, we fail to ascribe normative standing to them. I suggest that in cases of hermeneutical injustice, the unsympathetic hearer denies us our fair share of the very basic recognition that we deserve. In Anna's case, she is denied the respect of being treated as equal to her classmate Bob; due to her social group membership, she was judged to be less worthy of (epistemic) recognition. This implies that it is not a virtue of a good person to be epistemically just, but rather the very basis of treating others as full persons. It is thus a serious wrong when we fail to live up to this basic component of social interaction. We owe it to everyone.

\section{Counteracting Hermeneutical Injustice in Academia}

We can now conclude that to counteract the damaging effects of hermeneutical injustice in academia, we have to acknowledge the relational character of justice that is highlighted by theories of recognition. At stake in cases of exclusion and discrimination in academia is someone's normative status-it is not just a question of disrespect but of dehumanizing another person. It is not merely about who can achieve a career in academia, that is, who gets jobs, is invited as a keynote speaker, is published, and so on. It is also about whose self-recognition can develop adequately. That is, justice has to do with what treatment vis-à-vis other persons a (woman-)philosopher deserves in academia. Iris Young argues that justice should be concerned with social group differences that grant some social groups more power than others and that explicitly acknowledging these differences is necessary for counteracting mistreatment and oppression (Young 1990). Furthermore, hermeneutical injustice and misrecognition are structural problems and they demand a structural solution. Fricker's suggestion of epistemic virtues as a remedy to hermeneutical injustice can indeed help in some cases, but they are ill equipped to tackle the problem in general. ${ }^{24}$ This becomes especially clear in the example of women in academia. Had Anna's application for graduate funding been approved, her future would have been better but the problem of misrecognition of women in academia would not have been addressed at all. Had Anna's funding been rejected but she had met a sympathetic ear, someone who gave her due recognition as a victim of discrimination, Anna's personal life would have been better but, again, the general problem of the misrecognition of women in academia would not have been addressed. Thus, in the case of hermeneutical injustice in academia, we need to acknowledge the structural discrimination and exclusion that some social groups suffer so as to find fruitful ways to resist it. Once we do so, we have laid the foundations for 
tackling hermeneutical injustice in academia-along both the structural and the personal dimensions-because we have established a common ground according to which women's narratives of discrimination can be heard.

Acknowledgments. I am thankful for valuable feedback on earlier versions of this article from the members of the colloquium on Practical Philosophy at Freie Universität Berlin, especially Stefan Gosepath, Tamara Jugov, Henning Hahn, Mirjam Müller, Jekaterina Markow, and Tully Rector. I am extremely grateful for many wonderful conversations on the topic of this article with Jacob Blumenfeld, Christine Bratu, Matt Congdon, and Karen Ng. Finally, I am very thankful to two anonymous referees for insightful comments that have pressed me to think more deeply about many of the points that I make in the article and that have without doubt helped to make it better.

\section{Notes}

1 For interesting investigations of the relation between epistemic injustice and recognition, see Giladi and McMillan 2018; Giladi and McMillan forthcoming.

2 For reasons of simplicity, I speak of hermeneutical injustice as a "problem of misrecognition" in the following, having in mind (1) and (2). I am extremely grateful to one of the anonymous reviewers for helping me to clarify the relation of hermeneutical injustice and misrecognition in this way.

3 Michael Doan brings forward an argument for how theories of epistemic injustice can be used in fruitful ways by recognition theorists (Doan 2018). Here, I am interested in the other side of the coin, that is, how theories of hermeneutical injustice can benefit from recognition theory.

4 This example and the accompanied discussion of this case as an instance of hermeneutical injustice is discussed in detail in Bratu and Hänel (2019). I am deeply grateful to Christine Bratu for many insightful discussions and the joint work on this topic.

5 Part of why Anna fails to conceptualize her experience adequately is the overall social climate that she experiences at the university. It is likely that, as a young woman, she did not receive much positive feedback on her ideas and her writing, other students interrupted her, male students were praised in class even though they raised the same questions that she had raised earlier, she was not encouraged to continue studying philosophy, and so on (cf. Haslanger 2008; Antony 2012).

6 Fricker draws a distinction between cases of systematic hermeneutical injustice and cases of incidental hermeneutical injustice. Here, I am interested only in systematic hermeneutical injustice.

7 Although this is often omitted, it should be mentioned that Carmita Wood suffers from hermeneutical injustice not only because she is a woman, but because she is a black woman. Black women are subjected to sexual violence, including sexual harassment, in even greater numbers than other women. This fact does not change anything about the theory Fricker brings forward, but it highlights the ways in which intersectionality plays a role in our epistemic theories (cf. Berenstain 2016).

8 This is in contrast to the forms of hermeneutical injustice discussed by Jenkins 2016, in which the relevant concepts exist, but the agent uses a distorted working understanding instead.

9 For a full genealogy of the notion of recognition, see Taylor 1994.

10 Linda Nicholson has questioned how far Taylor's theory of recognition and identity is applicable to feminist claims. She argues that Taylor is wrong about the way he thinks of identity differentiations in regard to multiculturalism (Nicholson 1996). Although I think that Nicholson is correct, her issues touch mostly on Taylor's discussion of recognition and multiculturalism, and are not directly relevant for my argument here. I will therefore not discuss them further.

11 Some feminists have criticized theories of recognition grounded in Hegel's idea of the master-slave dialectic, for example, in Honneth and Taylor. Kelly Oliver, for example, argues that as long as we understand social relations as essentially antagonistic struggles for recognition, we have a hard time explaining how these struggles can ever lead to ethical social relations or compassionate personal relations (Oliver 2010). Most recognition theorists think of recognition as necessary for a sense of self, but they also think of subjectivity as based on antagonism and thus undermine the dialogical character of recognition. Furthermore, struggles for recognition become struggles against those in power and are therefore part of the pathology of oppression instead of counteracting it. Similarly, Estelle Ferrarese criticizes the lack of analysis of power or authority in most recognition theories. According to her, vulnerability is inherent in the concept of recognition because recognition relies on "the need to constitute the other as an authority in 
order to be recognized" (Ferrarese 2009, 606). Even though I subscribe to the idea that recognition is necessary for successful identity-formation, I do not take on board Honneth's (and others') idea of struggle as necessary for gaining recognition. Instead, I think that the most useful social relations of recognition are relations of care and dialogue and not of struggle and antagonism. In fact, I find it baffling to think of the master-slave dialectic instead of a relation of care when it comes to recognition. Thank you to Lea Prix and Jacob Blumenfeld for countless debates on these issues.

12 Others have suggested that there is a fourth and more elementary form of recognition that grounds the others. Theories of elementary recognition are concerned with how reason can enter the world in general. Scholars who argue for elementary recognition take a neo-Hegelian stance and claim that human agents cooperatively reconstruct the world (cf. Pinkard 1994; Pippin 2008; Ikäheimo and Laitinen 2011). As social agents, we rely on mutual recognition to give us and others epistemic authority and to enable the construction of a normative space of reasons.

13 Honneth evokes a similar idea to what I call "self-recognition," namely "a positive relation-to-self." Although nothing much hangs on the wording, it should be noted that his explication of a positive relation-to-self is slightly different from mine.

14 It might seem that epistemic injustice with its focus on testimonial injustice is a much better candidate to be paired with the concept of recognition. Paul Giladi, Jane McConkey, Matthew Congdon, and Liz Disley have explored the relation between epistemic injustice and misrecognition, with McConkey focusing on testimonial injustice and recognition theories (McConkey 2004; Disley 2015, chap. 5; Congdon 2017; Giladi 2018).

15 See Dotson 2011 for a detailed argument on how speakers are dependent on the reciprocity given by the hearer and how the lack of reciprocity can lead to epistemic violence.

16 I say more in the following about the notion of "giving recognition" in the sense of esteem or respect. Obviously, outside of family or romantic relations, we do not have a moral requirement to give love.

17 Although I focus here on the problem of a lack of self-recognition in academia, I contend that what I say about the relationship between hermeneutical injustice and theories of recognition can be fruitfully used for other contexts as well.

18 I want to thank Jekaterina Markow for this insight.

19 Language and dialogue are here meant to encompass a whole range of modes of expression and are not restricted to the words we utter (Taylor 1994, 32).

20 Remember the rather famous quote from Beauvoir about her philosophical encounters with Sartre and her resulting epistemic self-doubt: "Day after day, and all day long I measured myself against Sartre, and in our discussions I was simply not in his class.... 'I'm no longer sure what I think, or even if I think at all,' I noted, completely thrown" (Beauvoir 1959, 344, quoted in Fricker 2007, 51).

21 For a detailed explanation of identity and status, see the discussion between Linda Alcoff and Nancy Fraser (Alcoff 2007; Fraser 2007).

22 It is because instances of misrecognition are grounded in institutionalized patterns of cultural value that we can see how misrecognition and maldistribution go hand in hand (Fraser 2007, 310).

23 I contend that Fricker's virtue-theoretical approach fails in some cases (for example, in Anna's case) and that because hermeneutical injustice is a structural injustice, the virtue-theoretical approach that Fricker develops should be supplemented by a recognition-theory approach in terms of respect (institutional as well as individual). To be clear, I do not want to argue that epistemic justice is not a virtue or that recognition theory necessarily has to work outside a virtue-theoretical approach; instead, I merely state that recognition theory opens up possibilities for structural remedies that are not in terms of virtue. 24 For a similar point, see Anderson 2012; Giladi 2018.

\section{References}

Aguilar, Rudy, and Narina Nunez Nightingale. 1994. The impact of specific battering experiences on the self-esteem of abused women. Journal of Family Violence 9 (1): 35-45.

Alcoff, Linda. 2007. Fraser on redistribution, recognition, and identity. European Journal of Political Theory 6 (3): 255-65.

Anderson, Elizabeth. 2012. Epistemic justice as a virtue of social institutions. Social Epistemology 26 (2): 163-73. 
Antony, Louise. 2012. Different voices or perfect storm: Why are there so few women in philosophy? Journal of Social Philosophy 43 (3): 227-55.

Archard, David. 2007. The wrong of rape. Philosophical Quarterly 57 (228): 375-93.

Beauvoir, Simone de. 1959. Memoirs of a dutiful daughter. Trans. James Kirkup. London: Penguin.

Berenstain, Nora. 2016. Epistemic exploitation. Ergo 3 (22): 569-90.

Bernstein, Jay. 2015. Torture and dignity: An essay on moral injury. Chicago and London: University of Chicago Press.

Bratu, Christine, and Hilkje Hänel. 2019. On varieties of hermeneutical injustice. Unpublished manuscript.

Bratu, Christine and Kristina Lepold. 2018. Recognition and feminist thought. In Handbuch Anerkennung, ed. Ludwig Siep, Heikki Ikäheimo, and Michael Quante. Wiesbaden: VS Springer.

Brison, Susan. 2002. Aftermath: Violence and the remaking of a self. Princeton and Oxford: Princeton University Press.

Congdon, Matthew. 2017. What's wrong with epistemic injustice? Harm, vice, objectification, and misrecognition. In The Routledge handbook of epistemic injustice, ed. Ian James Kidd, José Medina, and Gaile Pohlhaus. New York: Routledge.

Congdon, Matthew. 2018. "Knower" as an ethical concept: From epistemic agency to mutual recognition. Feminist Philosophy Quarterly 4 (4): article 2.

Crerar, Charlie. 2016. Taboo, hermeneutical injustice, and expressively free environments. Episteme 13 (2): 195-207.

Disley, Liz. 2015. Hegel, love and forgiveness: Positive recognition in German idealism. London and New York: Routledge.

Doan, Michael. 2018. Resisting structural epistemic injustice. Feminist Philosophy Quarterly 4 (4): article 5.

Dotson, Kristie. 2011. Tracking epistemic violence, tracking practices of silencing. Hypatia 26 (2): 236-57.

Fanon, Frantz. 1952/2008. Black skin, white masks. New York: Grove Press.

Ferrarese, Estelle. 2009. "Gabba-Gabba, we accept you, one of us": Vulnerability and power in the relationship of recognition. Constellations 16 (4): 604-14.

Fraser, Nancy. 2003. Social justice in the age of identity politics: Redistribution, recognition, and participation. In Redistribution or recognition? A Political-philosophical exchange, ed. Nancy Fraser and Axel Honneth. London: Verso.

Fraser, Nancy. 2007. Identity, exclusion, and critique: A response to four critics. European Journal of Political Theory 6 (3): 305-38.

Fricker, Miranda. 2007. Epistemic injustice: Power and the ethics of knowing. Oxford: Oxford University Press.

Gardner, John, and Stephen Shute. 2000. The wrongness of rape. In Oxford essays in jurisprudence, ed. Jeremy Horder. Oxford: Oxford University Press.

Giladi, Paul. 2018. Epistemic injustice: A role for recognition. Philosophy and Social Criticism 44 (2): 141-58.

Giladi, Paul, and Nicola McMillan, eds. 2018. Epistemic injustice and recognition theory. Special issue: Feminist Philosophy Quarterly 4 (4).

Giladi, Paul, and Nicola McMillan, eds. Forthcoming. Epistemic injustice and the philosophy of recognition. New York and London: Routledge

Hänel, Hilkje. 2017. Power, pedagogy, and the "women problem": Ameliorating philosophy. Analytic Teaching and Philosophical Praxis 38 (1):17-28.

Haslanger, Sally. 2008. Changing the ideology and culture of philosophy: Not by reason (alone). Hypatia 23 (2): 210-23.

Honneth, Axel. 1995. The struggle for recognition: The moral grammar of social conflicts. Cambridge, Mass.: MIT Press.

Honneth, Axel. 2011. Das Recht der Freiheit: Grundriss einer Demokratischen Sittlichkeit. Berlin: Suhrkamp.

Hull, George. 2017. Black consciousness as overcoming hermeneutical injustice. Journal of Applied Philosophy 34 (4): 573-92.

Hutchison, Katrina, and Fiona Jenkins, eds. 2013. Women in philosophy: What needs to change? New York: Oxford University Press.

Ikäheimo, Heikki, and Arto Laitinen. 2011. Introduction. In Recognition and social ontology, ed. Heikki Ikäheimo and Arto Laitinen. Leiden and Boston: Brill. 
Jenkins, Katharine. 2016. Rape myths and domestic abuse myths as hermeneutical injustices. Journal of Applied Philosophy 33 (4): 394-421.

Keshky, Mogeda El Sayed El, and Yasser Abdelazim Abdelmangoud Samak. 2017. The development of selfesteem in children: Systematic review and meta analysis. International Journal of Psychology and Behavior Analysis 3: 128.

Kidd, Ian, José Medina, and Gaile Pohlhaus, eds. 2017. The Routledge handbook of epistemic injustice. New York: Routledge.

Kompridis, Nikolas. 2007. Struggling over the meaning of recognition. European Journal of Political Theory 6 (3): $277-89$.

Lane, John, Andrew M. Lane, and Anna Kyprianou. 2004. Self-efficacy, self-esteem and their impact on academic performance. Social Behavior and Personality 32 (3): 247-56.

Lippert-Rasmussen, Kasper. 2017. The philosophy of discrimination: An introduction. In The Routledge handbook of the ethics of discrimination, ed. Kasper Lippert-Rasmussen. New York: Routledge.

Maitra, Ishani. 2018. New Words for Old Wrongs. Episteme 15 (3): 345-62.

McConkey, Jane. 2004. Knowledge and acknowledgement: "Epistemic injustice" as a problem of recognition. Politics 24 (3): 198-205.

Medina, José. 2017. Varieties of hermeneutical injustice. In The Routledge handbook of epistemic injustice, ed. Ian James Kidd, José Medina, and Gaile Pohlhaus. New York: Routledge.

Medina, José. 2018. Misrecognition and epistemic injustice. Feminist Philosophy Quarterly 4 (4): 1-16.

Mikkola, Mari. 2016. The wrong of injustice. Oxford: Oxford University Press.

Miller, Sarah. 2009. Moral injury and relational harm: Analyzing rape in Darfur. Journal of Social Philosophy 40 (4): 504-23.

Neuhouser, Fred. 2000. Foundations of Hegel's social theory: Actualizing freedom. Cambridge, Mass.: Harvard University Press.

Nicholson, Linda. 1996. To be or not to be: Charles Taylor and the politics of recognition. Constellations 3 (1): $1-16$.

Oliver, Kelly. 2010. Witnessing: Beyond recognition. Minneapolis: University of Minnesota Press.

Pinkard, Terry. 1994. Hegel's phenomenology: The sociality of reason. Cambridge, UK: Cambridge University Press.

Pippin, Robert. 2008. Hegel's practical philosophy: Rational agency as ethical life. Cambridge, UK: Cambridge University Press.

Pohlhaus, Gaile. 2012. Relational knowing and epistemic injustice: Toward a theory of willful hermeneutical ignorance. Hypatia 27 (4): 715-35.

Saul, Jennifer. 2013. Implicit bias, stereotype threat, and women in philosophy. In Women in philosophy: What needs to change? ed. Katrina Hutchison and Fiona Jenkins. Oxford and New York: Oxford University Press.

Steele, Claude. 2010. Whistling Vivaldi: And other clues to how stereotypes affect us. New York: W. W. Norton.

Taylor, Charles. 1994. The politics of recognition. In Multiculturalism, ed. Charles Taylor. Princeton: Princeton University Press.

Valkenburg, Patti, Jochen Peter, and Alexander P. Schouten. 2006. Friend networking sites and their relationship to adolescents' well-being and social self-esteem. Cyber Psychology \& Behavior 9 (5): 584-90.

Wylie, Alison. 2011. Women in philosophy: The costs of exclusion. Hypatia 26 (2): 374-82.

Yancy, George. 2008. Situated black women's voices in/on the profession of philosophy. Hypatia 23 (2): 155-59.

Young, Iris Marion. 1990. Justice and the politics of difference. Princeton: Princeton University Press.

Zurn, Christopher. 2010. Introduction. In The philosophy of recognition: Historical and contemporary perspectives, ed. Hans-Christoph Schmidt am Busch and Christopher Zurn. Plymouth, UK: Lexington Books.

Hilkje C. Haenel currently works as a research and teaching associate of philosophy at the Freie University in Berlin and will take up a job as assistant professor at the University of Potsdam soon. She has a $\mathrm{PhD}$ in philosophy from Humboldt-University of Berlin, Germany, a liberal arts degree from the European College of Liberal Arts (now Bard College Berlin), a BA-degree in philosophy and English literature from Georg- 


\section{Hilkje C. Hänel}

August University of Göttingen, and a MA-degree in philosophy from Sheffield University. Her research combines various topics including questions of feminist methodology, feminist epistemology, ideology, recognition, and emancipation. Recently, she published What Is Rape? with Transcript Publishers.

Cite this article: Hänel HC (2020). Hermeneutical Injustice, (Self-)Recognition, and Academia. Hypatia 35, 336-354. https://doi.org/10.1017/hyp.2020.3 